\title{
Změny předpisů pro oceňování věcí nemovitých od 1 . ledna 2022
}

\author{
Albert Bradáč ${ }^{a^{*}}$, Petr Polák ${ }^{b}$ \\ a emeritni profesor, Vysoké učení technické v Brně, Ústav soudního inženýrství, Brno \\ ${ }^{b}$ Ministerstvo financi $\check{C} R$
}

Amendments to the Valuation of Immovable Property from the $1^{\text {st }}$ January 2022

\begin{abstract}
Abstrakt
V článku jsou uvedeny a komentovány změny v oceňování nemovitostí, které přináší novela oceňovací vyhlášky č. 441/2013 Sb. k 1. lednu 2022.
\end{abstract}

Klíčová slova: nemovitost, nemovitá věc, stavba, právo stavby, pozemek, věcné břemeno, rychle rostoucí dřeviny, cena.

\section{1. ÚVODEM}

K 1. lednu 2022 nabývá účinnosti vyhláška Ministerstva financí č. 424/2021 Sb., jež novelizuje vyhlášku č. 441/2013 Sb., k provedení zákona o oceňování majetku (oceňovací vyhláška), ve znění vyhlášek č. 199/2014 Sb., č. 345/2015 Sb., č. 53/2016 Sb., č. 443/2016 Sb., č. 457/2017 Sb., č. 188/2019 Sb. a č. 488/2020 Sb. Účelem předkládaného příspěvku je seznámit čtenáře podrobněji $\mathrm{s}$ touto novelou, včetně důvodů, jež $\mathrm{k}$ jejímu vydání vedly. $\mathrm{V}$ příspěvku jsou místy použity výňatky $\mathrm{z}$ důvodové zprávy MF ČR [4].

Zákon o oceňování majetku č. 151/1997 Sb. má obecnou povahu; vymezuje základní pojmy, způsoby a principy oceňování a odkazuje v podrobnostech u některých taxativně vyjmenovaných ustanovení na prováděcí předpis, oceňovací vyhlášku č. 441/2013 Sb. Vyhláška stanovuje způsoby ocenění, základní ceny, koeficienty, přirážky a srážky pro oceňování pozemků, staveb, trvalých porostů, práva stavby, věcných břemen, újmy a jiných majetkových práv. Pro objektivnost oceňování nemovitých věcí je třeba tuto vyhlášku pravidelně aktualizovat $\mathrm{v}$ návaznosti na vývoj cen na trhu s nemovitými věcmi v České republice.

Při aktualizaci základních cen v novele oceňovací vyhlášky Ministerstvo financí jako zpracovatel vychází z analytického vyhodnocení údajů o cenách nemovitých věcí, a to jak cen realizovaných, tak i nabídkových. Takto získané informace o cenách a jejich vývoji na trhu s nemovitými věcmi jsou vzájemně porovnávány a dále upravovány pro účely aktualizace vyhlášky.

\section{Abstract}

The article lists and comments on changes in real estate valuation, which are also amended by the Valuation Decree No. 441/2013 Coll. as of January 1, 2022.

Keywords: property, real thing, building, construction law, land, easements, fast growing woody plants, price.

Vzhledem k nedávnému zrušení daně z nabytí nemovitých věcí nebyl nyní $\mathrm{k}$ dispozici dostatek údajů (dat) pro novelizaci základních cen pozemků a vybraných druhů staveb, které byly dříve o sjednaných cenách či cenách ze znaleckých posudků poskytovány $\mathrm{z}$ databáze Finančních úřadů. Tato skutečnost byla nahrazena daty a údaji o nemovitých věcech a jejich převodech na trhu v období 07/2019 až 05/2021, získanými z katastru nemovitostí, od bankovního sektoru, Českého statistického úřadu a z jiných zdrojů, obsahujících jak data o cenách sjednaných, tak případně nabídkových.

Zpracovatel v novele oceňovací vyhlášky rovněž řeší a zohledňuje připomínky vznesené odbornou veřejností, pokud jsou opodstatněné nebo prínosné pro objektivitu určovaných cen, a lze je aplikovat pro obecné použití. Respektoval přitom její znalost místních podmínek a používání právního předpisu v praxi.

Hlavní úpravy v novele spočívají:

- ve zrušení povinnosti odůvodnovat případné rozdíly mezi obvyklou cenou a cenou zjištěnou,

- v každoroční aktualizaci základních cen $Z C$ stavebních pozemků a dále $Z C$ některých staveb pro ocenění porovnávacím způsobem,

- v aktualizaci koeficientů změny cen staveb $K_{\mathrm{i}}$,

- V upřesnění nejasností textu, např́iklad u jiných pozemků resp. u poznámky pod tabulkou č. 2, vztahující se k opěrným bodům technické infrastruktury v př́loze č. 22a k oceňovací vyhlášce,

- V aktualizaci použití zjednodušeného způsobu ocenění u lesních porostů. 


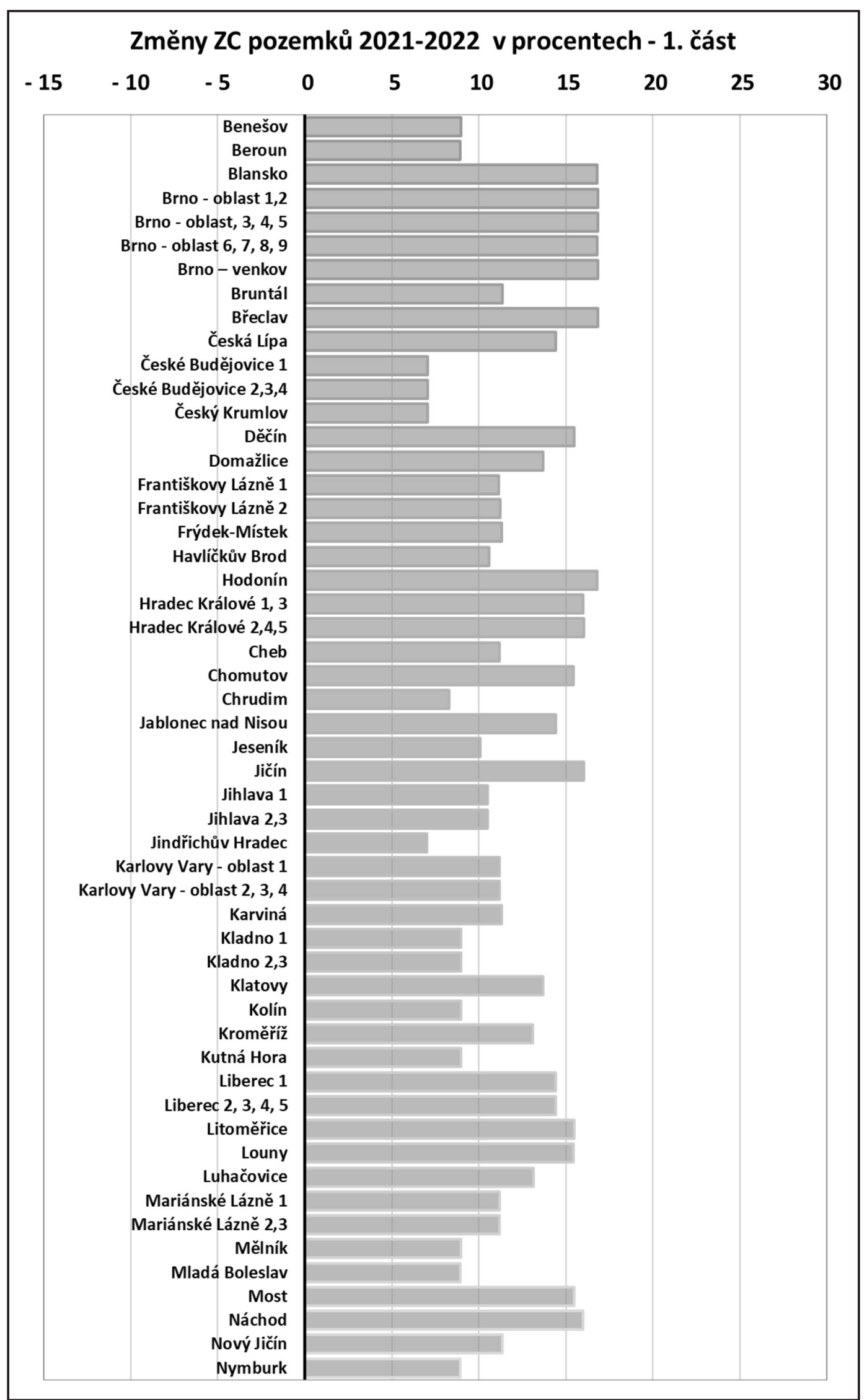

Obr. 1 Změny základních cen stavebních pozemků 2021/2022 u vyjmenovaných obcí resp. jejich částí v tabulce č. 1 v př́loze č. 2 oceňovací vyhlášky - část 1 (Zpracováni: vlastní).

Fig. 1 Changes in basic prices of building plots 2021/2022 in the listed municipalities resp. their parts in Table No. 1 in Annex No. 2 to the Valuation Decree - Part 1 (Processing: own). 


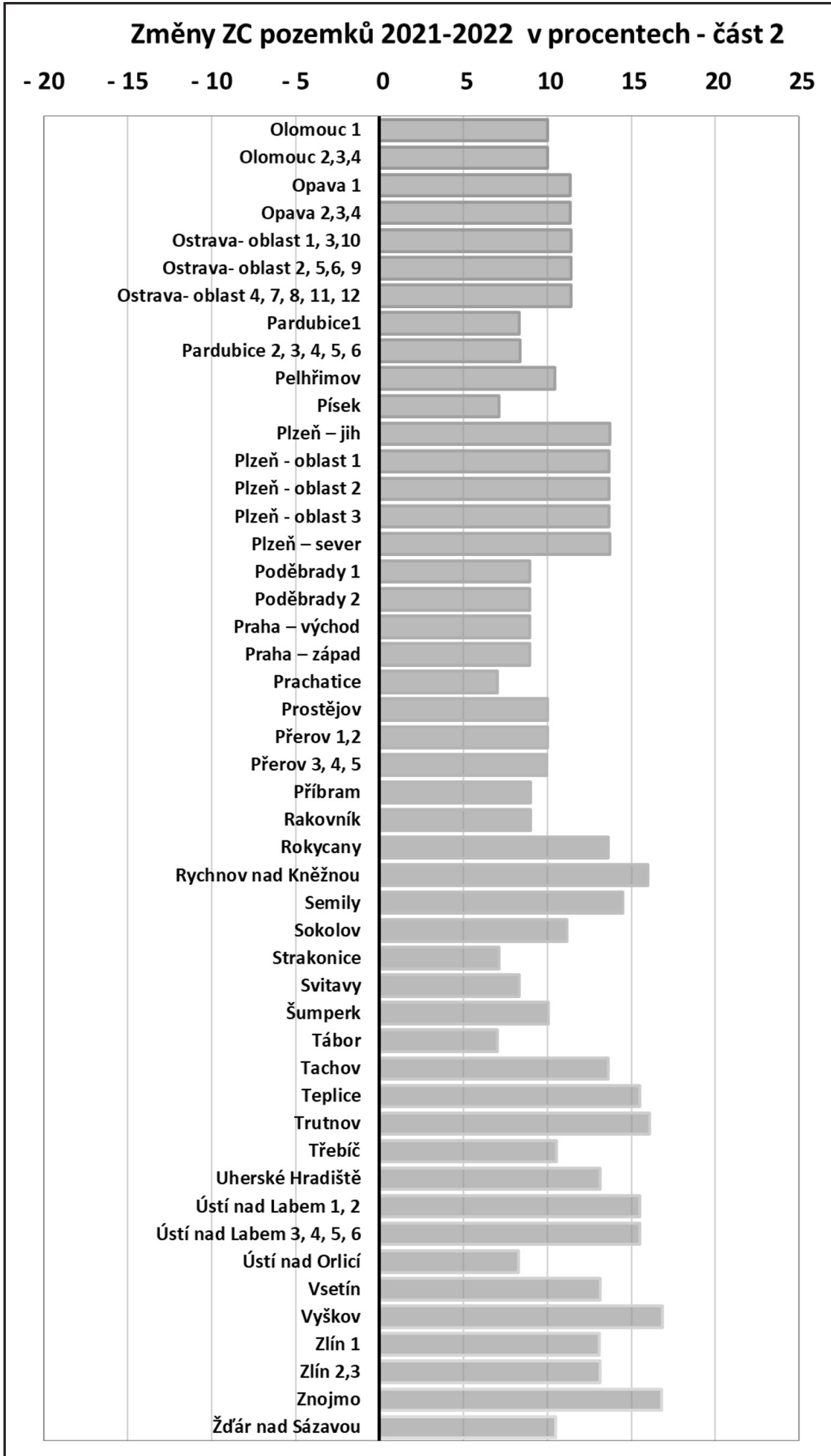

Obr. 2 Změny základnich cen pozemkủ 2021/2022 u vyjmenovaných obcí resp. jejich částí v tabulce č. 1 v přiloze č. 2 oceňovací vyhláškyčást 2 (Zpracování: vlastní).

Fig. 2 Changes in basic prices of building plots 2021/2022 in the listed municipalities resp. their parts in Table No. 1 in Annex No. 2 to the Valuation Decree - Part 2 (Processing: own). 
V př́loze č. 2 oceňovací vyhlášky v tabulce č. 1 jsou aktualizovány základní ceny za $\mathbf{m}^{2}$ stavebního pozemku ve vyjmenovaných obcích, jejich oblastech a okresech na základě sjednávaných cen a analýz údajů, které MF předávají územní pracoviště Finančních úřadů v návaznosti na ustanovení $§ 33$ odst, 3 zákona o oceňování majetku. Změny oproti loňské verzi oceňovací vyhlášky viz obr. č. 1 a 2; v Praze činí zvýšení obligátně 9,31\%.

Pozemky zemědělské ( $§ 11 \mathrm{ZOM}, \S 6 \mathrm{OV})$ - beze změn, přílohy rovněž beze změn.

Lesní pozemek a nelesní pozemek s lesním porostem $(\S 12$ ZOM, § 7 OV) - vzhledem ke zrušení daně z nabytí nemovitých věcí byl u oceňování lesního porostu zjednodušeným způsobem a u oceňování ovocných dřevin, vinné révy, okrasných rostlin a jejich smíšených porostů zjednodušeným způsobem odstraněn odkaz na tuto konkrétní daň. Předmětné zjednodušené způsoby ocenění zůstaly ponechány. Přitom zjednodušený způsob oceňování lesního porostu se uplatní při určení výnosové ceny a zjednodušený způsob oceňování ovocných dřevin, vinné révy, okrasných rostlin a jejich smíšených porostů se použije pro účely ocenění $v$ případě, že tak jiný právní předpis stanoví.

Pozemek vodní plochy, jiný pozemek ( $\$ 13$ ZOM, § 8 a 9 OV) - beze změn, prrílohy rovněž beze změn.

U nákladového způsobu ocenění staveb ( $§ 10$ až $30 \mathrm{OV})$ došlo jen k aktualizaci koeficientů změny cen staveb $\mathrm{K}_{i} \mathrm{v}$ př́loze č. 41 . Průběh koeficientu od roku 1994 je zřejmý z obr. 3. U průměru se zde jedná o prostý aritmetický průměr hodnot z př́lohy č. 41 .

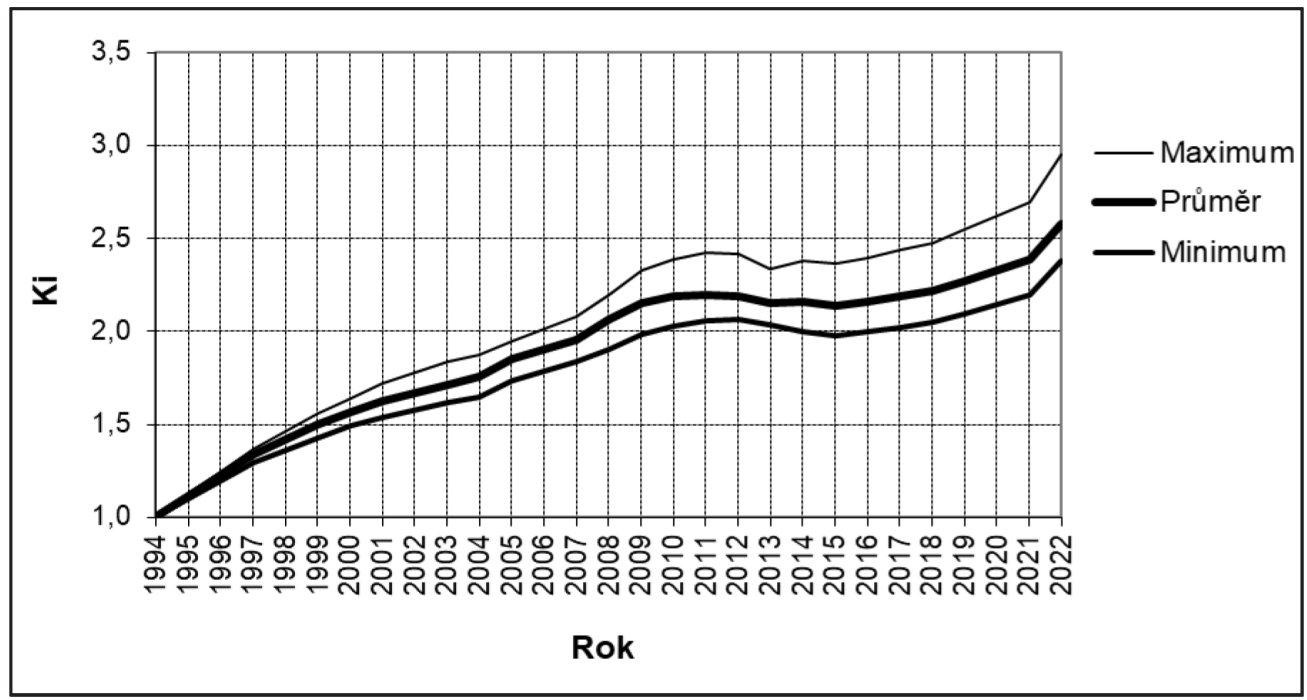

Obr. 3 Vývoj koeficientu změny cen staveb Ki v letech 1994 - 2022.

Fig. 3 Evolution of factor changes in prices of constructions Ki in the years 1994 to 2022.

Porovnávací způsob ocenění vybraných druhů staveb (§§ 34-38) - text nezměněn, nové jsou hodnoty základních cen $Z C$ v prílohách č. 24 až 27.

Na grafech v obr. 4 až 8 je uveden vývoj $Z C$ od roku 2009 (zavedeno ocenění porovnávacím způsobem) do roku 2022 (dř́ve tzv. IPC - indexovaná průměrná cena; s přechodem na $Z C$ a změnou metodiky zřejmě souvisejí skoky od roku 2013). U průměru se zde opět jedná o prostý aritmetický průměr hodnot z př́islušných př́iloh.

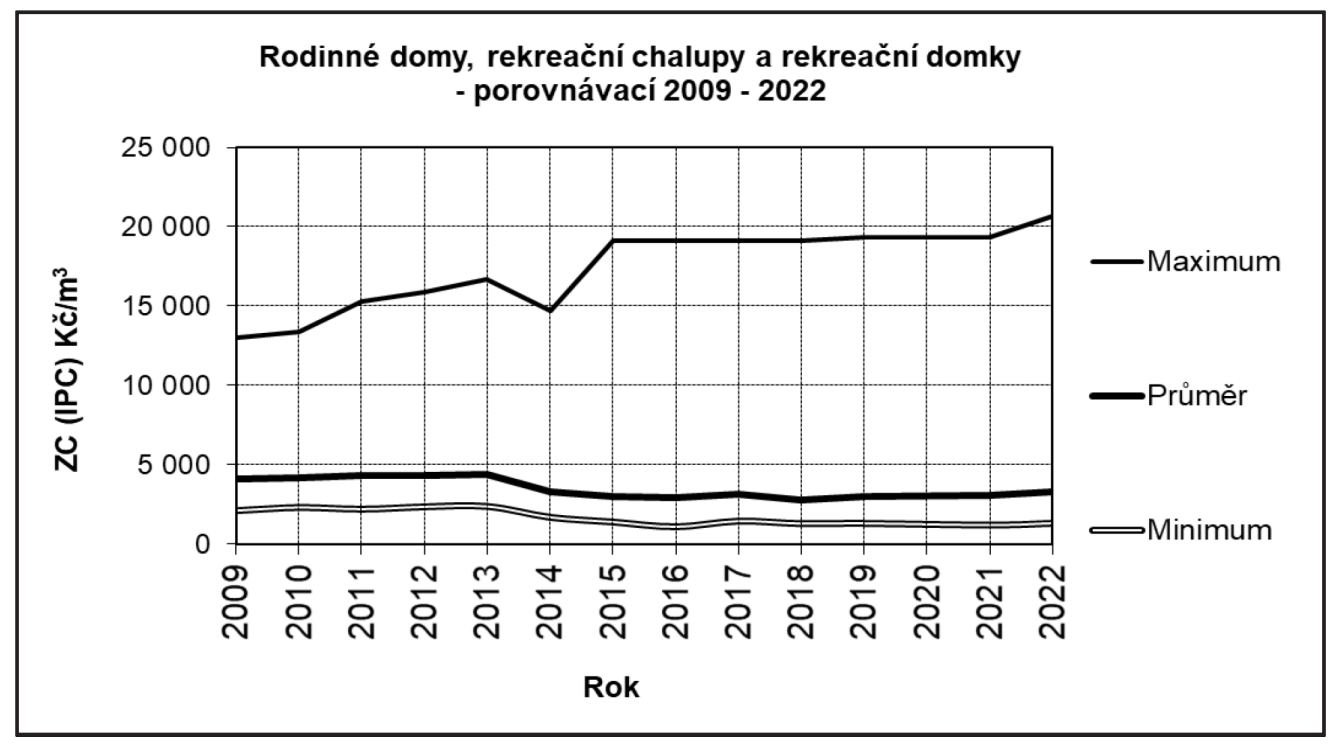

Obr. 4 Vývoj základnich cen ZC u porovnávaci metody v letech 2009-2022; rodinné domy, rekreační chalupy a rekreační domky.

Fig. 4 Evolution of basic prices ZC with comparative methods in the years 2009-2022; family houses, vacation cottages and recreational houses. 


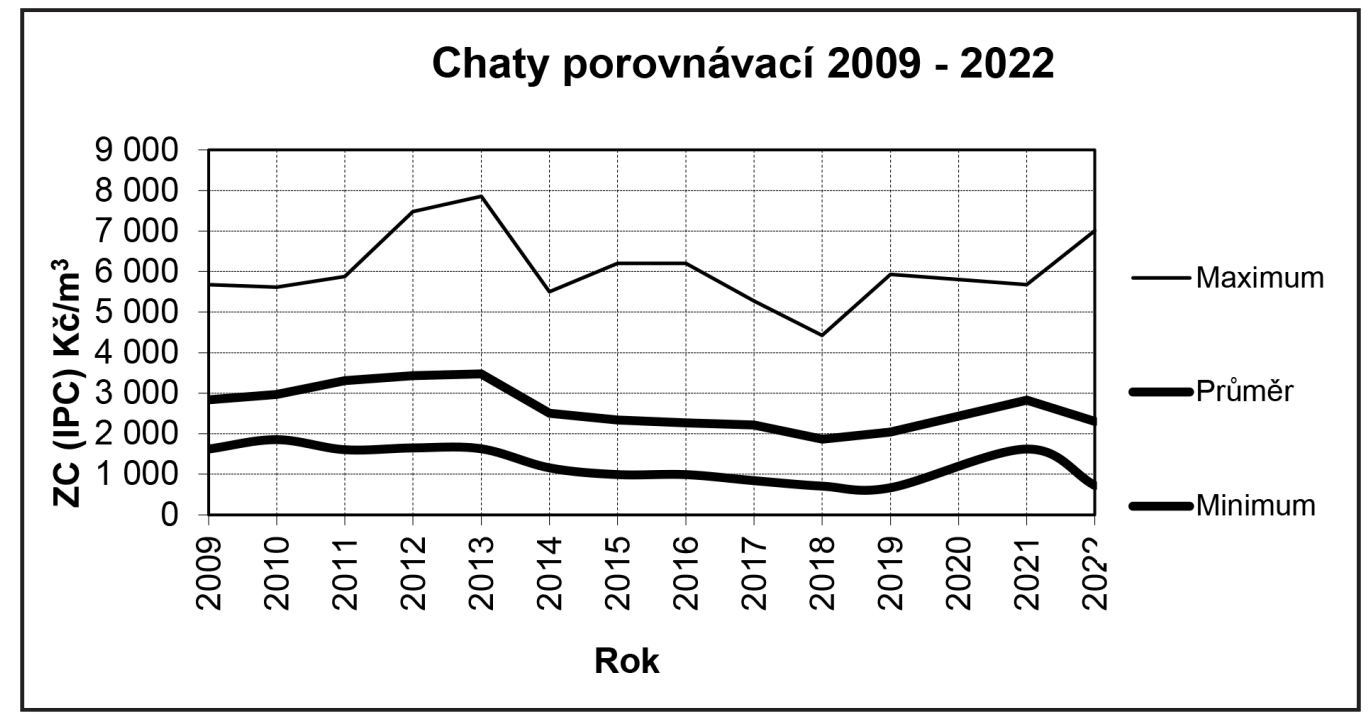

Obr. 5 Vývoj základních cen ZC u porovnávaci metody v letech 2009-2022; rekreační a zahrádkářské chaty.

Fig. 5 Evolution of basic prices ZC with comparative methods in the years 2009-2022; recreational and gardening cottages.

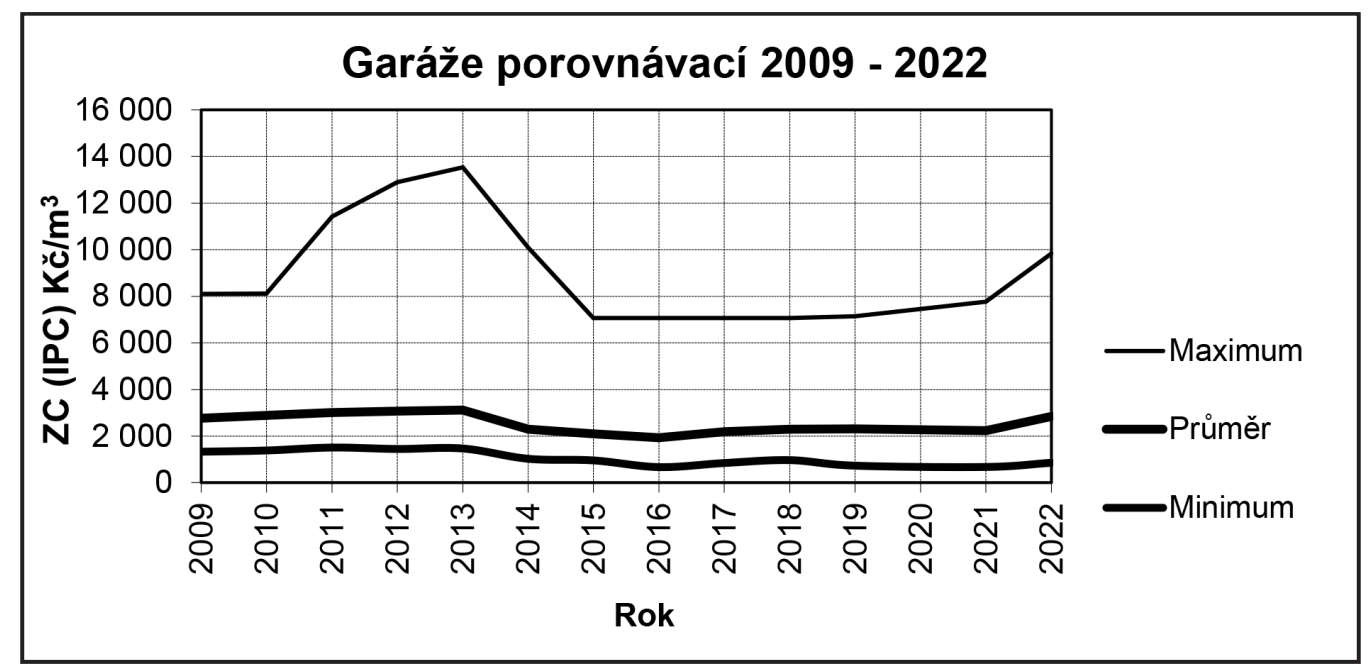

Obr. 6 Vývoj základnich cen ZC u porovnávaci metody v letech 2009-2022; garáže.

Fig. 6 Evolution of basic prices ZC with comparative methods in the years 2009-2022; garage.

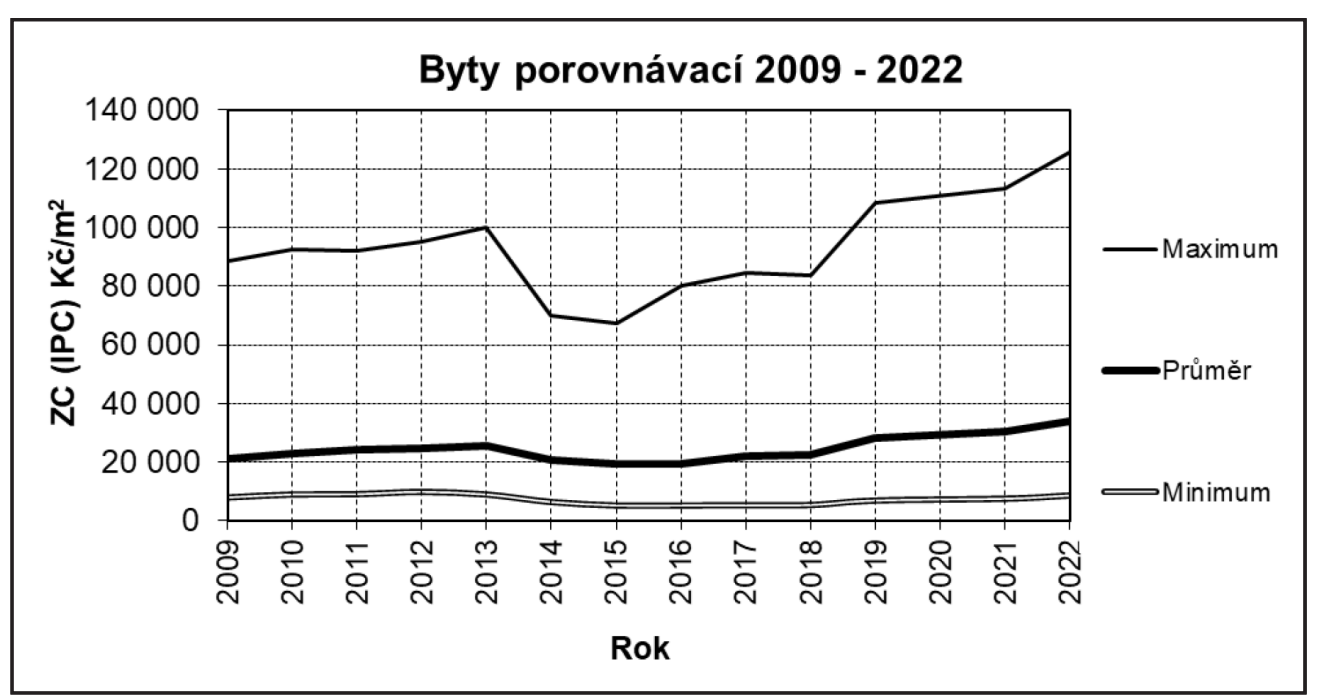

Obr. 7 Vývoj základnich cen ZC u porovnávaci metody v letech 2009-2022; byty.

Fig. 7 Evolution of basic prices ZC with comparative methods in the years 2009-2022; flats. 
Tab. 1 Přehled meziročních př́růstků průmèru ze základnich cen u porovnávacího způsobu ocenèní v letech 2010-2022.

Tab. 1 Overview of annual growth averages from basic prices by reference to the valuation in the years 2010-2022.

\begin{tabular}{|c|c|c|c|c|c|c|c|c|c|c|c|c|}
\hline \multicolumn{13}{|c|}{ Přírůstek průměru ze ZC u porovnávacího způsobu ocenění staveb v daném roce oproti roku předchozímu (\%) } \\
\hline Rok & 2010 & 2011 & 2012 & 2013 & 2014 & 2015 & 2016 & 2017 & 2018 & 2019 & 2020 & 2021 \\
\hline Garáže & 4,45 & 4,23 & 2,26 & 1,46 & $-26,46$ & $-8,45$ & $-7,99$ & 13,13 & 5,03 & 0,78 & $-3,12$ & 25,78 \\
\hline Byty & 7,68 & 5,54 & 2,67 & 2,19 & $-18,34$ & $-6,4$ & 0,74 & 11,8 & 2,86 & 26,95 & 7,14 & 12,17 \\
\hline Chaty & 4,39 & 11,74 & 3,73 & 1,18 & $-28,0$ & $-6,43$ & $-3,31$ & $-2,16$ & $-15,75$ & 9,39 & 38,70 & $-18,53$ \\
\hline $\begin{array}{l}\text { Rodinné domy, rekreační } \\
\text { chalupy a domky }\end{array}$ & 1,05 & 4,62 & 0,02 & 1,55 & $-24,8$ & $-8,96$ & $-1,93$ & 6,58 & $-12,29$ & 8,82 & 0,97 & 9,17 \\
\hline
\end{tabular}

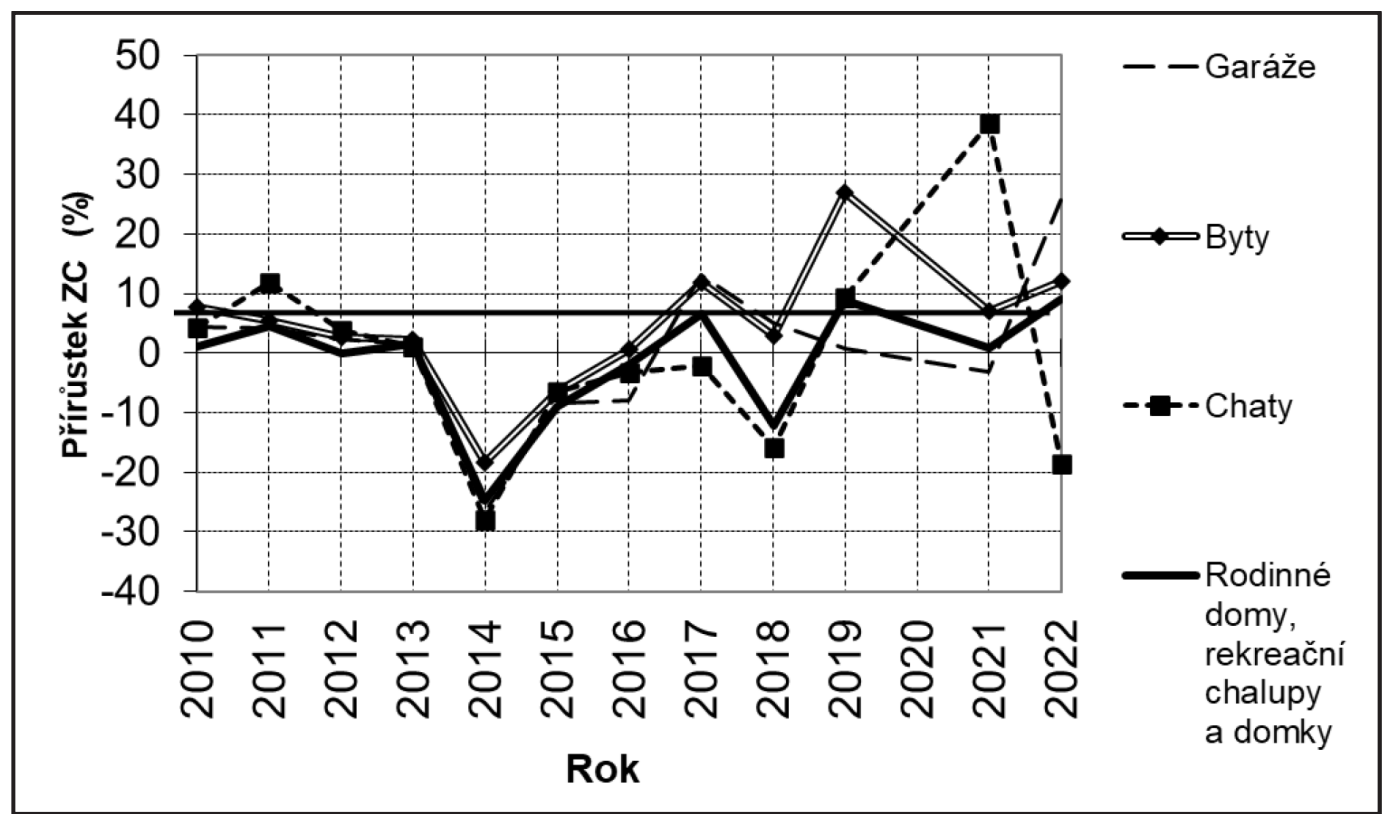

Obr. 8 Vývoj meziročního prírůstku průměru základní ceny u porovnávací metody v letech 2010-2022.

Fig. 8 Evolution of annual increase in the average basic price by comparison methods in the years 2010-2022.

Oceňování kombinací nákladového a výnosového způsobu (§§ 31 až $33 \mathrm{OV})$ - zde při novelizaci nedošlo k žádným změnám.

Věcná práva k nemovitým věcem (právo stavby, věcné břemeno) - rovněž beze změn.

U trvalých porostů došlo ke změnám uvedeným výše, důvodem bylo zrušení zákona o dani z nabytí nemovitého majetku.

Společná, závěrečná a zrušovací ustanovení - beze změn.

Závěrem: Ministerstvo financí vydalo nový cenový výměr č. 01/2022 ze dne 3. prosince 2021, obsahující seznam zboží $\mathrm{s}$ regulovanými cenami, $\mathrm{v}$ němž již není ustanovení o max. ceně nemovitých věcí nabývaných státem. Současně byl zrušen výměr č. 01/2021, jenž tuto regulaci obsahoval. Skončila tedy regulace při koupi nemovitých věcí státem podle tohoto výměru; nadále ovšem platí ustanovení $\S 12$ odst. 4 a 5 zákona č. 219/2000 Sb., o majetku České republiky a jejím vystupování v právních vztazích, kde je omezení cenou podle cenového předpisu zachováno:

(4) Při úplatném nabývání majetku lze cenu ${ }^{16)}$ sjednat pouze do výše rovnajici se oceněni tohoto majetku podle zvláštního právního předpisu ${ }^{17)}$ a jde-li o majetek nabývanýv zahraničí, pouze do výše, která je v daném mistě a čase obvyklá. Ve veřejném zájmu může Ministerstvo financí dát předchozi souhlas ke sjednání ceny vyšší. To platí obdobně, je-li majetek nabýván v dražbě. ${ }^{17 a)}$

(5) Pokud sjednaná cena překroči výši př́pustnou podle odstavce 4 a nejde prritom o nabytí majetku $v$ dražběr ${ }^{17 a)}$ anebo $v$ zahraničí, je dohoda o ceně neplatná v rozsahu rozdílu, o který sjednaná cena připustnou výši překročila. Je-li úplatné nabytí majetku předmětem veřejné zakázky zadané podle zákona upravujicího zadávání veřejných zakázek platí odstavec 4 pouze v připadé, má-li být smlouva uzavrena na základě výsledku jednaciho ř́zeni bez uveřejnění.

Regulace nájemného z pozemků veřejné infrastruktury, na kterých není provozována podnikatelská činnost a slouží zejména jako občanské vybavení, zůstala zachována, jen se změnila jeho výše o přibližně $+10 \%$.

\section{LITERATURA}

[1] Zákon č. 151/1997 Sb., o oceňování majetku a o změně některých zákonů (zákon o oceňování majetku), ve znění pozdějších předpisů 
[2] Vyhláška č. 441/2013 Sb., k provedení zákona o oceňování majetku (oceňovací vyhláška), ve znění pozdějších předpisů.

[3] Vyhláška č. 424/2021 Sb., kterou se mění vyhláška č. 441/2013 Sb., k provedení zákona o oceňování majetku (oceňovací vyhláška), ve znění pozdějších předpisů.
[4] Ministerstvo financí - Odůvodnění novely pro LRV - 2021.

[5] BRADÁČ, A., POLÁK, P. Úřední oceňování majetku 2022. 1. vydání. Brno: Akademické nakladatelství CERM, Brno, 2022, 340 s. ISBN 978-80-7623-077-4

\section{Správná citace:}

BRADÁČ, A., POLÁK, P. Změny předpisů pro oceňování věcí nemovitých od 1. ledna 2022. Soudní inženýrství, 2021, 32(4), 19-25.

DOI: http://dx.doi.org/10.13164/SI.2021.4.19. ISSN 1211-443X. 